This item was submitted to Loughborough's Research Repository by the author.

Items in Figshare are protected by copyright, with all rights reserved, unless otherwise indicated.

\title{
Synthesis and evaluation of a novel ionophore based on a thiacalix[4]arene derivative bearing imidazole units
}

PLEASE CITE THE PUBLISHED VERSION

http://dx.doi.org/10.1039/c4nj01099j

\section{PUBLISHER}

(c) Royal Society of Chemistry

\section{VERSION}

SMUR (Submitted Manuscript Under Review)

\section{PUBLISHER STATEMENT}

This work is made available according to the conditions of the Creative Commons Attribution-NonCommercialNoDerivatives 4.0 International (CC BY-NC-ND 4.0) licence. Full details of this licence are available at: https://creativecommons.org/licenses/by-nc-nd/4.0/

\section{LICENCE}

CC BY-NC-ND 4.0

\section{REPOSITORY RECORD}

Zhao, Jiang-Lin, Hirotsugu Tomiyasu, Xin-Long Ni, Xi Zeng, Mark R.J. Elsegood, Carl Redshaw, Shofiur Rahman, P.E. Georghiou, and Takehiko Yamato. 2019. "Synthesis and Evaluation of a Novel lonophore Based on a Thiacalix[4]arene Derivative Bearing Imidazole Units". figshare. https://hdl.handle.net/2134/18333. 


\title{
ARTICLE
}

Cite this: DOI: $10.1039 /$ xoxxooooox

Received ooth January 2012, Accepted ooth January 2012

DOI: $10.1039 / \times 0 \times x 00000 x$

www.rsc.org/

\section{Synthesis and evaluation of a novel ionophore based on a thiacalix[4]arene derivative bearing imidazole units $\dagger$}

\author{
Jiang-Lin Zhao, ${ }^{\mathrm{a}}$ Hirotsugu Tomiyasu,, ${ }^{\mathrm{a}}$ Xin-Long Ni, ${ }^{b}$ Xi Zeng, ${ }^{\mathrm{b}}$ Mark R. J. Elsegood, ${ }^{\mathrm{c}}$ \\ Carl Redshaw ${ }^{\mathrm{d}}$ and Takehiko Yamato ${ }^{* a}$
}

$\mathrm{O}$-Alkylation of the flexible thiacalix[4]arene 1 with 2-chloromethyl-1-methyl- $1 \mathrm{H}$-imidazole 2 in the presence of $\mathrm{Na}_{2} \mathrm{CO}_{3}$ or $\mathrm{K}_{2} \mathrm{CO}_{3}$ afforded mono-O-alkylation product 3 in $29-51 \%$ yield, along with recovery of the starting compound. In contrast, the same reaction in the presence of $\mathrm{Cs}_{2} \mathrm{CO}_{3}$ gave only one pure stereoisomer, namely 1,3-alternate-4; other possible isomers were not observed. Alkali metal salts such as $\mathrm{Na}_{2} \mathrm{CO}_{3}$ and $\mathrm{Cs}_{2} \mathrm{CO}_{3}$ can play an important role in the conformer distribution via a template effect. The conformations of the receptors, mono-Oalkylation product $\mathbf{3}$ and that of 1,3-alternate-4, have been confirmed by X-ray crystallography. Furthermore, the complexation properties of the receptor 1,3-alternate-4 toward selected alkali/transition metal cations are reported. The two-phase solvent extraction data indicated that 1,3-alternate-4 exhibited a stronger extraction efficiency for transition metals over alkali metals. The dichromate anion extraction ability of 1,3-alternate-4 showed that it could serve as an efficient extractor of $\mathrm{HCr}_{2} \mathrm{O}_{7}{ }^{-} / \mathrm{Cr}_{2} \mathrm{O}_{7}{ }^{2-}$ anions at low $\mathrm{pH}$.

\section{Introduction}

Calix $[n]$ arenes have attracted great attention as ionophoric receptors $^{1}$ and potential enzyme mimics $^{2}$ in host-guest chemistry. Over the past few decades, extensive research has been carried out to study and mimic biological systems such as enzymes, antibodies, and DNA by designing novel receptors. ${ }^{3}$ Molecular recognition is a fundamental phenomenon in biology, and tuning of the affinity of a receptor for a ligand by the environment is key for the regulation of biological processes. With biomimetic receptors in mind, Reinaud et al. have recently developed the first supramolecular system that mimics metalloenzyme active sites by the selective binding of a neutral molecule to a metal center incorporated inside a tertbutylcalix[6]arene functionalized at alternate positions by three imidazole groups. ${ }^{4}$ The imidazole unit is an essential metal binding site in metalloproteins. One or more imidazole units are bound to metal ions in almost all copper and zinc metalloproteins to bring about profound effects on their biological actions. ${ }^{5}$ In these metalloproteins the threedimensional structures of the macromolecules facilitate the coordination of metal ions by independent side-chain residues. Therefore, ligands containing two or more imidazole rings can potentially mimic the binding sites and catalytic activities of these enzymes. ${ }^{6}$ It was found by Reinaud et al. ${ }^{7}$ and by Huang et $a .^{8}{ }^{8}$ that calix $[n]$ arenes can be converted to neutral ligands by the introduction of imidazole groups at the $\mathrm{OH}$ groups. They demonstrated that the metal selectivity was dependent on the calix $[n]$ arene ring size and the systems exhibited remarkably high transition metal ion selectivity. Recently, it was found that receptors with imidazole groups bind anions by hydrogen bonding between the imidazolium rings and the guest anion. ${ }^{9}$ Given that the ring size and flexibility are different between calix[4]arene and thiacalix[4]arene, it is interesting to assess what kind of ionophoric cavity tetra-thiacalix[4]arene imidazole-substituted compounds will provide.

Chromium and its compounds are widely used in plating, leather tanning, dyes, cements, and in the photographic industry, all of which produces large quantities of toxic pollutants. ${ }^{10}$ High concentrations of hexavalent chromium ion is toxic to the human body, and to livestock. For example, a level of chromium i.e. $>0.25 \mathrm{mg} . \mathrm{L}^{-1}$ is responsible for a serious threat to aquatic as well as human life in nearby areas. ${ }^{11}$ In nature Cr(VI) usually exists in the form of the acid radical, thus developing a positively charged ionophore for chromium has great research significance.

To the best our knowledge, however, no precedent exists for molecular design of such tetrathiacalix[4]arene-based ionophores. Thus in this study, we aimed to synthesize tetrasubstituted tetrathiacalix[4]arene-bearing imidazole moieties at the lower rim in order to investigate their inclusion properties with metal ions. The tetrakis[2-(1-methyl- $1 H$-imidazolyl) methoxy]-tetrathiacalix[4]arene with a 1,3-alternate 
conformation, should have the appropriate encapsulating ionophilic cavity.

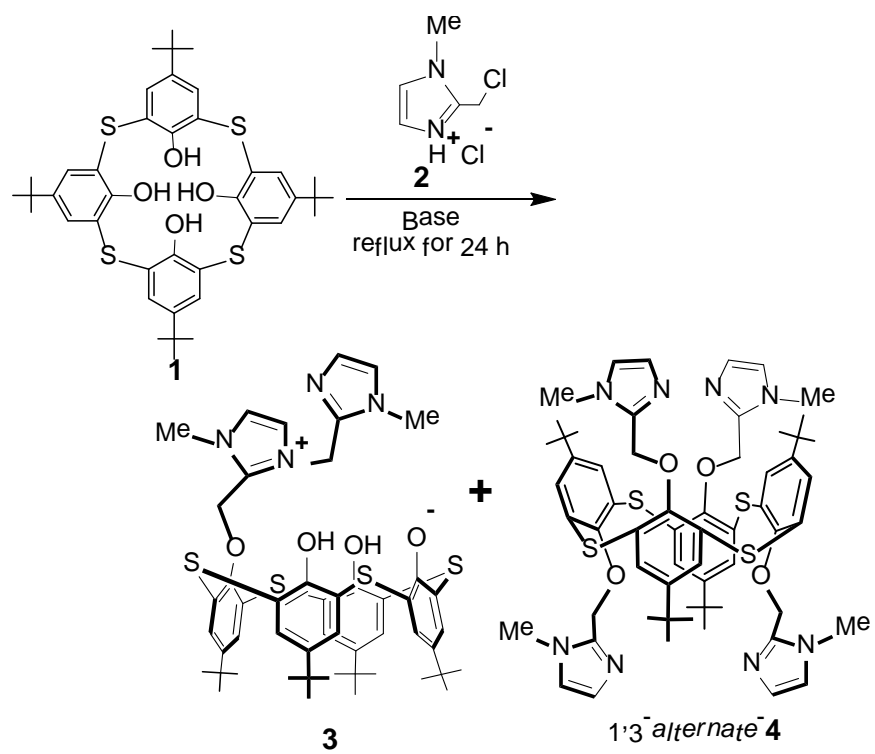

Scheme 1 O-Substitution reaction of tetraol 1 with 2-chloromethyl-1-methyl$1 \mathrm{H}$-imidazole 2.

Table 1 O-Substitution reaction of tetraol 1 with 2-chloromethyl-1-methyl$1 H$-imidazole 2.

\begin{tabular}{|c|c|c|c|c|c|c|}
\hline \multirow{2}{*}{$\mathrm{R}^{\mathrm{un}}$} & \multirow{2}{*}{ Base } & \multirow{2}{*}{ Solvent } & \multirow{2}{*}{$\begin{array}{l}\mathbf{2} / \mathbf{1} \\
{[\mathrm{mol} / \mathrm{mol}]}\end{array}$} & \multicolumn{3}{|c|}{ Yield (\%) ${ }^{a \cdot b}$} \\
\hline & & & & 3 & $1,3^{-} a_{\text {lternate }} \mathbf{4}$ & $\begin{array}{l}\mathrm{Recover}_{\mathrm{y}} \\
\text { of } \mathbf{1}\end{array}$ \\
\hline 1 & $\mathrm{Na}_{2} \mathrm{CO}_{3}$ & Acetone & 12 & $45[30]$ & 0 & 55 \\
\hline 2 & $\mathrm{Na}_{2} \mathrm{CO}_{3}$ & MeCN & 12 & 43 [29] & 0 & 57 \\
\hline 3 & $\mathrm{~K}_{2} \mathrm{CO}_{3}$ & Acetone & 12 & 89 [51] & 0 & 11 \\
\hline 4 & $\mathrm{CS}_{2} \mathrm{CO}_{3}$ & Acetone & 12 & 0 & 100 [66] & 0 \\
\hline
\end{tabular}

${ }^{a}$ The yield determined by ${ }^{1} \mathrm{H}$ NMR spectroscopy. ${ }^{b}$ Isolated yields are shown in square brackets.

\section{Results and discussions}

The thiacalix[4]arene derivatives $\mathbf{3}$ and 1,3-alternate-4 were synthesized by the method shown in Scheme 1. O-Alkylation of the flexible macrocycle 1 with 2-chloromethyl-1-methyl- $1 H$-imidazole hydrochloride 2 in the presence of $\mathrm{Na}_{2} \mathrm{CO}_{3}$ in refluxing acetone or acetonitrile led to a mixture of unexpected compound $\mathbf{3}$ in (30\% and $29 \%$ yield, respectively) with a high recovery (55\% and $57 \%$, respectively) of the starting compound in spite of the conditions (a large excess of 2-chloromethyl-1-methyl- $1 \mathrm{H}$-imidazole hydrochloride 2). A similar reaction carried out in the presence of $\mathrm{K}_{2} \mathrm{CO}_{3}$, afforded a higher yield (51 \%) of compound 3, however possible isomers were still not observed (Scheme 1 and Table 1). The sole formation of compound $\mathbf{3}$ may be related to the following factors: the distance between the lone pair on the nitrogen atom and the smaller size $\mathrm{Na}^{+}$or $\mathrm{K}^{+}$was too long to allow for efficient binding. The reactivity of 2-chloromethyl-1-methyl-1H-imidazole hydrochloride $\mathbf{2}$ was sufficient for further alkylation of the imidazolyl group based on the thiacalix[4]arene, due to the existence
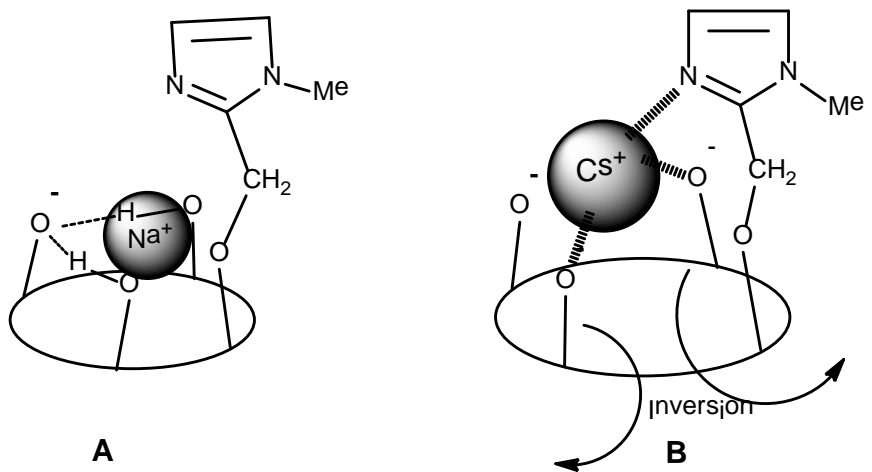

Fig. 1 Ring inversion of $O$-alkylation intermediate of tetraol $\mathbf{1}$ and immobilization by metal template.

of a lone pair. Furthermore, as revealed by the results of an X-ray analysis, there exist two strong intramolecular hydrogen bonds between the hydroxyl groups and a phenolate oxygen $\mathrm{O}(3)$ of compound 3 (Fig. 2). Probably, these intramolecular hydrogen bonds $\left(\mathrm{OH} \bullet \bullet \mathrm{O}^{-} \bullet \cdot \mathrm{OH}\right)$ were capable of holding a larger substituent in position that then obstructed access of another imidazole molecule to the reaction centre. When $\mathrm{Na}^{+}$or $\mathrm{K}^{+}$was employed as a base, the conformation was preferentially immobilized to the cone, the intramolecular hydrogen bonds could not be broken (Fig. $1 \mathrm{~A}$ ), and so only the formation of compound $\mathbf{3}$ was possible.

A much larger contribution by $\mathrm{Cs}^{+}$to the template effect might be anticipated versus $\mathrm{Na}^{+}$, as reported by Harrowfield. ${ }^{12}$ The larger size of $\mathrm{Cs}^{+}$could enable efficient binding with the lone pair of the nitrogen atom; the larger $\mathrm{Cs}^{+}$might enlarge the radius of the cyclophane ring of tetraol $\mathbf{1}$ to form sufficient space to allow ring inversion and afford a thermodynamically stable 1,3-alternate conformer as illustrated in Fig. 1(B). The intramolecular hydrogen bonds are broken in the 1,3-alternate conformer. As a result, when $\mathrm{Cs}_{2} \mathrm{CO}_{3}$ was used as a base, only the tetra-substituted product 1,3alternate-4 was obtained in $66 \%$ yield when using a large excess of 2-chloromethyl-1-methyl- $1 \mathrm{H}$-imidazole hydrochloride 2 . The expected isomer was finally observed (Scheme 1 and Table 1).

The structures of $\mathbf{3}$ and 1,3-alternate-4 were identified by ${ }^{1} \mathrm{H}$ NMR, IR, MS spectra, elemental analyses and by X-ray crystallography. The ${ }^{1} \mathrm{H}$ NMR spectrum of $\mathbf{3}$ showed three singlets for the tert-butyl protons $(\delta 0.34,1.18$, and $1.34 \mathrm{ppm})$ and the relative intensity was $1: 1: 2$, indicating a mono-substituted structure for compound 3 (Fig. S1, see ESI†). Interestingly, it was found that two methyl protons for the Imme $\mathrm{CH}_{3}$ were observed at $\delta 3.78(\mathrm{~s}, 3 \mathrm{H})$ ppm and $\delta 4.33(\mathrm{~s}, 3 \mathrm{H}) \mathrm{ppm}$, which strongly suggested that there were two imidazolyl groups present. Furthermore, the resonance for the methylene protons appeared as a singlet at $\delta 6.05(\mathrm{~s}, 2 \mathrm{H}) \mathrm{ppm}$, and an unexpected methylene group was observed as a singlet at an unusually down-field position ( $\delta 6.41 \mathrm{ppm}, 2 \mathrm{H}$ ). However, on consideration of the ${ }^{1} \mathrm{H}$ NMR spectrum, there was only one possible 
structure for compound 3, i.e., the mono-substituted cone structure. These observations strongly suggested that in compound 3 two of the imidazole rings were not di-substituted at two opposite $\mathrm{O}$ atoms of thiacalix[4]arene, rather the system was mono-substituted. In fact,

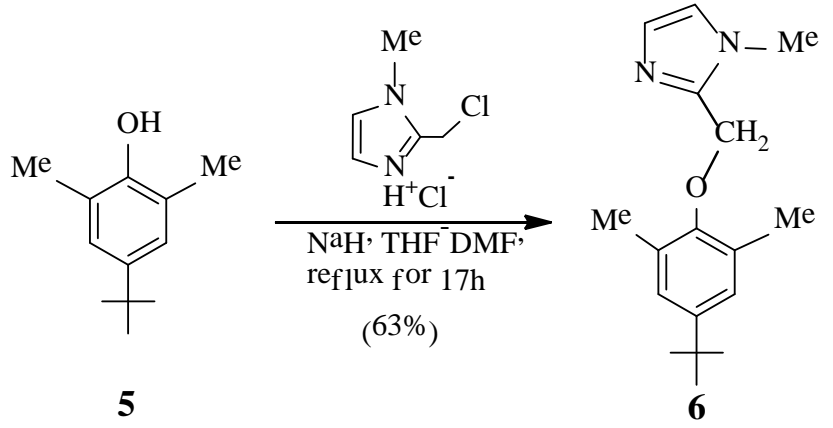

Scheme 2 Synthesis of the reference compound 6.

Table 2 Chemical shifts of 1,3-alternate-4 and reference compound $\mathbf{6}^{a}$

\begin{tabular}{|c|c|c|c|}
\hline \multirow{2}{*}{$\mathrm{com}_{\mathrm{p}}$ oun $_{\mathrm{d}}$} & \multicolumn{3}{|c|}{$\mathrm{Ch}^{\mathrm{em}}{ }_{\mathrm{i}}^{\mathrm{cal}}$ Shifts, $\delta\left(\mathrm{pp}^{\mathrm{m}}\right)$} \\
\hline & $\mathrm{N} \mathrm{Me}$ & $\mathrm{H} 4$ & H5 \\
\hline $1,3^{-} a_{l t}$ ernate ${ }_{4}^{-}$ & $2 \cdot 51$ & $6 \cdot 69$ & $6 \cdot 99$ \\
\hline 6 & $3 \cdot 70$ & $6 \cdot 82$ & $6 \cdot 94$ \\
\hline$\Delta \delta^{b}$ & $+1 \cdot 19$ & $+0 \cdot 13$ & ${ }^{-} 0 \cdot 05$ \\
\hline
\end{tabular}

${ }^{a} \Delta \delta$ value is the difference of the chemical shift between 1,3-alternate-4 and reference compound 6 in $\mathrm{CDCl}_{3}$ at $27{ }^{\circ} \mathrm{C}$. ${ }^{b}$ A plus sign (+) denotes a shift to lower magnetic field, whereas, a negative sign (-) denotes a shift to higher magnetic field.

the second imidazole ring was bound to the first imidazolyl group, and the latter had been already appended to the thiacalix[4]arene, and had not separately bound to the opposite $\mathrm{O}$ atom of the thiacalix[4]arene.

In contrast, the ${ }^{1} \mathrm{H}$ NMR spectrum of 1,3-alternate- 4 showed a singlet for the tert-butyl protons at $\delta 1.14 \mathrm{ppm}$, a singlet for ArOCH $\mathrm{H}_{2} \mathrm{Imme}$ at $\delta 5.17 \mathrm{ppm}$ and a singlet for the aromatic protons at $7.26 \mathrm{ppm}$, respectively, indicating a $C_{4}$-symmmetric structure for the 1,3-alternate-4 (Fig. S4, see ESI $\dagger$ ). Interestingly, the heteroaromatic protons of the imidazole rings of 1,3-alternate-4 were exposed to the ring current shielding effect operated by the phenolic cyclophane ring of the parent scaffold, and were found to resonate at higher field compared to those of the reference compound $\mathbf{6}$, which was prepared by $O$-alkylation of 4-tert-butyl-2,6-dimethylphenol ${ }^{13}$ with 2chloromethyl-1-methyl-1H-imidazole hydrochloride in the presence of $\mathrm{NaH}$ (Scheme 2). Table 2 showed that the magnitude of this shielding, calculated as the difference between pertinent imidazole protons of 1,3-alternate-4 and reference compound 6, increased significantly at the $\mathrm{H}_{4}$ and $\mathrm{N}-\mathrm{Me}$ protons. The remarkable shielding effect experienced by the $\mathrm{H}_{5}$ proton $(-0.05 \mathrm{ppm})$ may be attributed to the repulsion between the nitrogen atoms in the imidazole rings. ${ }^{14}$

X-ray crystallographic analyses confirmed the molecular structures of $\mathbf{3}$ and 1,3-alternate- $\mathbf{4}$ as shown in Figures 2 and 3. The results for $\mathbf{3}$ confirmed that two of the imidazole rings were not

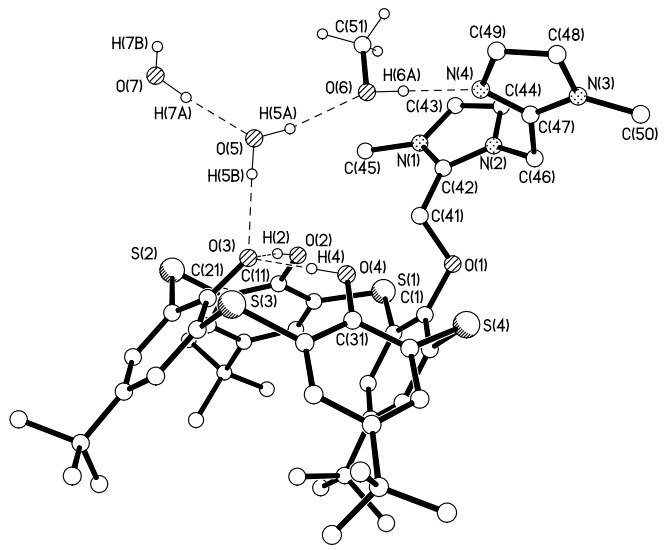

(a)

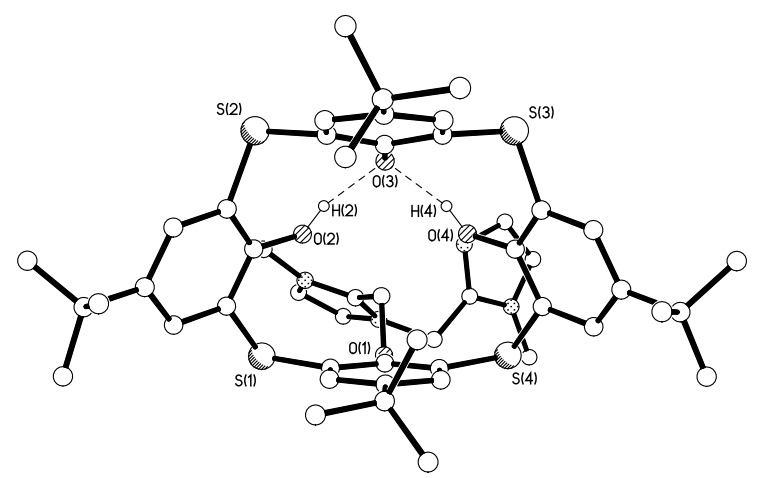

(b)

Fig. 2 X-ray structure of compound 3 showing (a) the asymmetric unit including water and methanol of crystallisation, and (b) the upper-rim groups, viewed on to the calix-ring plane. Hydrogen atoms have been omitted for clarity except for those involved in H-bonding or on solvent of crystallisation.

disubstituted at two opposite $\mathrm{O}$ atoms of thiacalix[4]arene, but that mono-substitution had occurred. The second imidazole ring was bound to the first imidazolyl group which had been fixed to the thiacalix[4]arene, and not to the opposite $\mathrm{O}$ atom. $\mathrm{O}(3)$ bears a 1charge and $\mathrm{H}$-bonds to two adjacent phenolic groups. $\mathrm{N}(2)$ bears a $1+$ charge. Rings at $\mathrm{O}(1)$ and $\mathrm{O}(3)$ were pinched in $\{\mathrm{C}(4) \cdots \mathrm{C}(24)=$ $6.062(3) \AA$ \}, while those at $\mathrm{O}(2)$ and $\mathrm{O}(4)$ were splayed out $\{C(14) \cdots C(34)=9.965(3) \AA\}$. The most noteworthy feature was the extent to which the ring at $\mathrm{O}(3)$ was bent in to fill the unsually wide open thiacalix[4]arene cavity, and thus the thiacalix[4]arene was very distorted. The asymmetric unit comprises one thiacalixarene molecule, one methanol and two waters of crystallisation (Fig. 2).

For 1,3-alternate-4, the molecule resides on the $\overline{4}$ axis, so one quarter is unique. Two imidazolyl groups in the compound point upwards, with the another two pointing downwards. Interestingly, 
the four imidazolyl groups are kept away from the cavity; the shortest distance between the carbon of the $\mathrm{N}-\mathrm{Me}$ and the carbon of the phenyl ring is $3.48 \AA$ (e.g. $C(15)-C(1)$ ). Given this, the two phenyl rings which are face-to-face are almost parallel, and form a square cavity with $C(4) \cdots C\left(4^{\prime}\right)=5.998(4) \AA$. All of the adjacent S-S distances are about $5.54 \AA$, the S-S-S bond angle is about $89.76^{\circ}$ (Fig. 3).

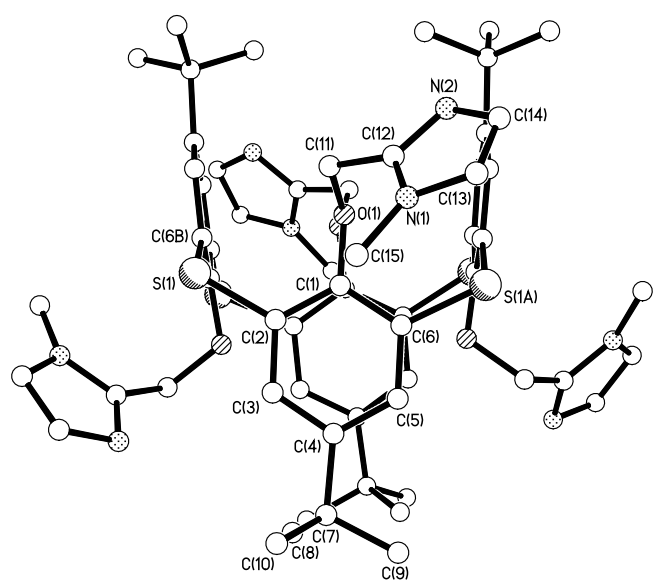

(a)

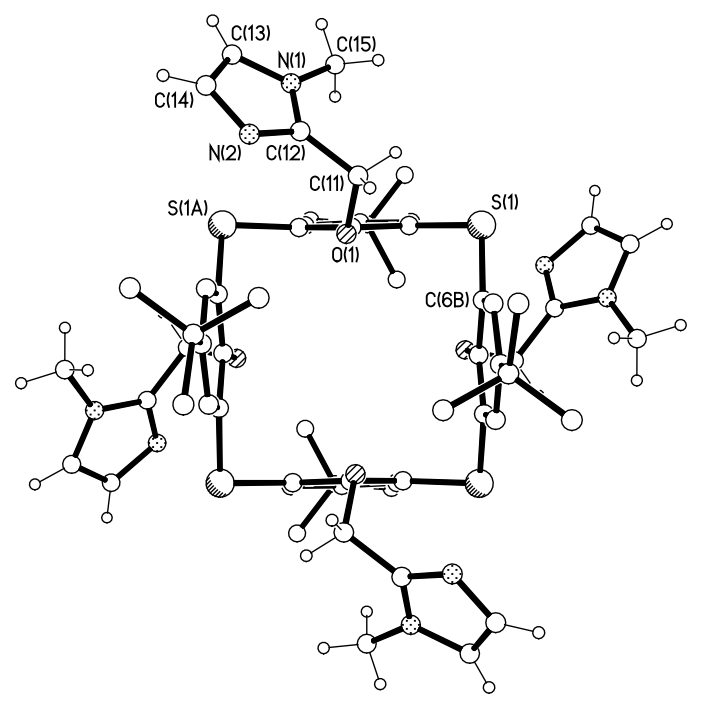

(b)

Fig. 3 X-ray structure of compound 1,3-alternate-4 showing (a) the side view (b) the upper-rim groups, viewed on to the calix-ring plane. Hydrogen atoms have been omitted for clarity in (a).

In order to investigate the ionophoric affinity of 1,3-alternate-4 for metal cations, the extractability of the metal ions was determined by solvent extraction from the aqueous to the organic phase. We noted that the extraction of transition metals was higher than the extraction of alkali metals by 1,3-alternate-4 (Fig. 4). This might be due to the transition metals having a higher nuclear charge and smaller radius. The free $d$ orbitals of the transition metals are capable of accepting lone pairs from the ligand, and given the electron configuration of the metal, it is easy to feedback d electrons to the ligand. In this experiment, ligand $\mathbf{4}$ had lone pairs of electrons for donation (providing the nitrogen atoms), and therefore was able to

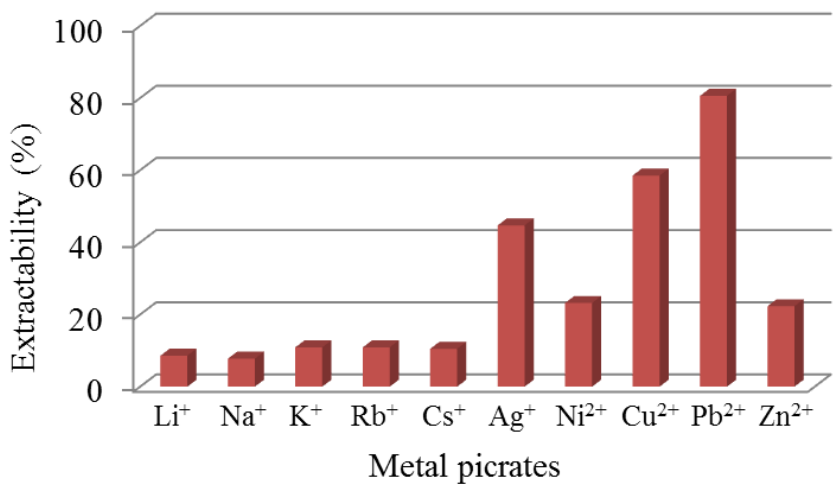

Fig. 4 Extraction percentages of metal picrates with 1,3-alternate-4 ([Host $]=$ $2.5 \times 10^{-4} \mathrm{M}$ in $\mathrm{CH}_{2} \mathrm{Cl}_{2}$, [Guest] $=2.5 \times 10^{-4} \mathrm{M}$ in water at $25^{\circ} \mathrm{C}$ ).

form stable complexes. However, alkali metal and alkaline earth metals, in contrast to the transition metal, have low polarization, with an inert gas structure, poor ability to form complexes, and the stability of their complexes was poor.

Due to the existence of three metal-binding sites, including the parent cavities, the 1,3-substituted as well as 2,4-substituted imidazole moieties, there were several possibilities for metal complexation in the 1,3-alternate-4 with guest molecules and $1: 1$ or 1 : 2 metal complexation might well be possible. Therefore, the continuous variation Job's plot method was applied to determine the stoichiometries of 1,3-alternate-4 with $\mathrm{Ag}^{+}$ions as an example in a two-phase extraction experiment $\left(\mathrm{H}_{2} \mathrm{O}-\mathrm{CH}_{2} \mathrm{Cl}_{2}\right)$. The percentage extraction for 1,3-alternate-4 (Job plot) supported the formation of a 1 : 2 complex with $\mathrm{Ag}^{+}$cations. When 1,3-alternate-4 and $\mathrm{Ag}^{+}$ cation concentrations were changed systematically, the percentage extraction reached a maximum between 0.6 and 0.7 mole, which indicated that 1,3-alternate-4 formed a $1: 2$ complex with $\mathrm{Ag}^{+}$ (Fig.5).

Furthermore, in order to look further into the binding

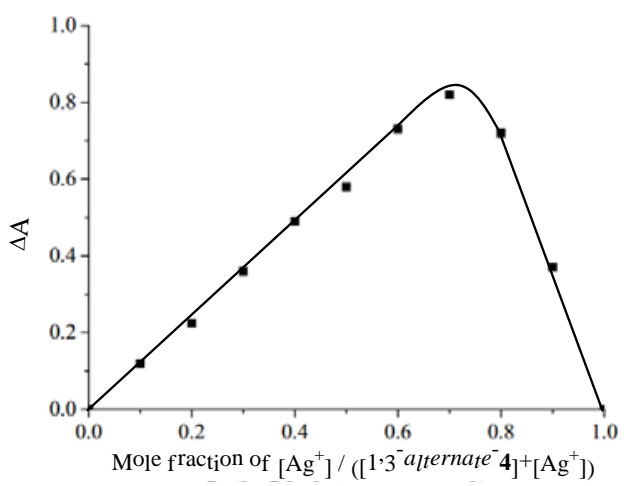

Fig. 5 Job plot for complexation of 1,3-alternate-4 with $\mathrm{Ag}^{+}$ion. 


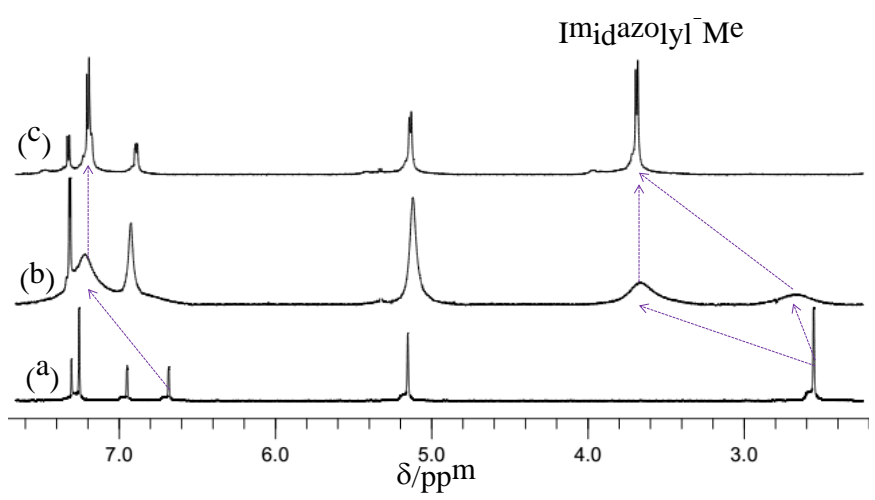

Fig. $6{ }^{1} \mathrm{H}$ NMR spectral changes of 1,3-alternate-4 $\left(8 \times 10^{-3} \mathrm{M}\right)$ on addition of $\mathrm{AgClO}_{4}\left(300 \mathrm{MHz}, \mathrm{CDCl}_{3}: \mathrm{CD}_{3} \mathrm{CN}=10: 1\right.$, [1,3-alternate-4] $=8 \times 10^{-3}$ $\mathrm{M}$ ). (a) Free 1,3-alternate-4; (b) in the presence of 1.0 equiv. of $\mathrm{AgClO}_{4 \text {; }}$ (c) in the presence of 2.0 equiv. of $\mathrm{AgClO}_{4}$.

properties of the receptor 1,3-alternate-4 with $\mathrm{Ag}+, 1 \mathrm{H}$ NMR titration experiments were carried out in CD3Cl:CD3CN $=10: 1$ solution. The chemical shift changes for compound 1,3-alternate-4 on complexation with $\mathrm{Ag}+$ are illustrated in Fig. 6. Significant change was observed for the imidazole- $\mathrm{N}-\mathrm{CH}_{3}$ protons after complexation of 1,3-alternate-4 with 1.0 equiv. $\mathrm{Ag}^{+}$; the chemical shift of the methyl group shifted dramatically downfield by +1.11 $\mathrm{ppm}$ at $\delta 3.65 \mathrm{ppm}$ (complexation) and $+0.11 \mathrm{ppm}$ at $\delta 2.65 \mathrm{ppm}$ (uncomplexed) as two broad singlets. On increasing the titration amount of $\mathrm{Ag}^{+}$to 2.0 equiv., a clear singlet at $\delta 3.69 \mathrm{ppm}$ was observed, which belonged to the methyl group. This chemical shift was almost same as the methyl group of reference compound $\mathbf{6}$. The adjacent imidazolyl-proton $\mathrm{H}_{4}$ was affected by the change of $\mathrm{N}-\mathrm{CH}_{3}$, and exhibited a shift downfield by $+0.52 \mathrm{ppm}$ at $\delta 7.22 \mathrm{ppm}$. These changes strongly suggested that $\mathrm{Ag}^{+}$was complexed by the imidazole moieties via $\mathrm{N} \cdot \mathrm{Ag}^{+}$interactions with these nitrogen atoms oriented outwards to inwards. These results also indicated that $\mathrm{Ag}^{+}$was complexed by all four imidazole moieties of the 1,3alternate-4, and a 1 : 2 complex was formed with retention of the original symmetry (conformationally frozen on the NMR time scale).

To better understand the chelating effect of imidazole fragments in the $\mathrm{Ag}^{+}$cation binding, the complexation $\mathrm{Ag}^{+}$by the host 1,3alternate-4 is shown in Fig. 7. From the results of the X-Ray analysis, the four imidazolyl groups are kept away from the cavity, the $\mathrm{N}-\mathrm{CH}_{3}$ of imidazolyl groups are close to the outward pointing phenyl ring, and the shortest distance between the carbon of $\mathrm{N}-\mathrm{CH}_{3}$ and the ipso carbon of phenyl ring is $3.48 \AA$ (e.g. $\mathrm{C}(15)-\mathrm{C}(1)$ ). Interestingly, when 1.0 equiv. $\mathrm{Ag}^{+}$was added to the solution of 1,3alternate-4, two imidazole groups captured one silver cation via $\mathrm{N} \cdots \mathrm{Ag}^{+}$interactions, and this led to these imidazole groups being oriented inwards towards the cavity. Under these conditions, the imidazole- $\mathrm{N}-\mathrm{CH}_{3}$ was removed from the shielding area to the deshielding area, and the chemical shift of the $\mathrm{N}-\mathrm{CH}_{3}$ proton recovered to $\delta 3.65 \mathrm{ppm}$. When 2.0 equiv. $\mathrm{Ag}^{+}$was added, a similar phenomenon was observed in the other two imidazole groups.

A preliminary evaluation of the anion binding efficiencies of the potential extractant 1,3-alternate-4 has been carried out by solvent extraction of $\mathrm{K}_{2} \mathrm{Cr}_{2} \mathrm{O}_{7}$ from aqueous solution into dichloromethane at different $\mathrm{pH}$ values as reported previously. ${ }^{15 a}$ From the extraction results given in Fig. 8, it was clear that 1,3-alternate-4 was effective for the extraction of dichromate anions at low $\mathrm{pH}$. This could be attributed to an ionpair (hydrogen bonded) complex formed in the two-phase extraction system following proton transfer to the nitrogen atoms of the imidazole units in 1,3-alternate-4 and then complexation of $\mathrm{Cr}_{2} \mathrm{O}_{7}{ }^{2-} / \mathrm{HCr}_{2} \mathrm{O}_{7}{ }^{-14} \cdot{ }^{14}$ However, the reference compound 6 showed almost no significant selective binding of dichromate anions even at low $\mathrm{pH}$. Based on these results, it is concluded that the thiacalix[4]arene unit plays an important role in confirming cooperative participation of the peripheral imidazole groups.

The evaluation of dichromate anion extraction efficiencies by calix $[n]$ arene derivatives has rarely been studied over the past decade. ${ }^{14,15}$ When higher concentrations of ligands (10 equiv.) to dichromate anions were employed in the extraction experiment, the maximum extraction efficiencies were $81.8 \%,{ }^{15 a} 23.0 \%,{ }^{15 b} 86.6 \%,{ }^{15 c} 72.0 \%,{ }^{15 d} 69.4 \%{ }^{15 e}$ and $73.7 \%{ }^{15 f}$ at lowest $\mathrm{pH}$. However, 1,3-alternate-4 exhibited outstanding extraction ability for dichromate anions, with the maximum percentage of extracted dichromate ions found to be $70.4 \%$ for 1,3-alternate-4 at a lower concentration (2 equiv.) when the $\mathrm{pH}$ of the aqueous solution was 1.5 (Fig. 8). In other words, 1,3-alternate-4 can serve as a highly effective extractant for the extraction of dichromate anions $\left(\mathrm{Cr}_{2} \mathrm{O}_{7}{ }^{2-} / \mathrm{HCr}_{2} \mathrm{O}_{7}{ }^{-}\right)$.

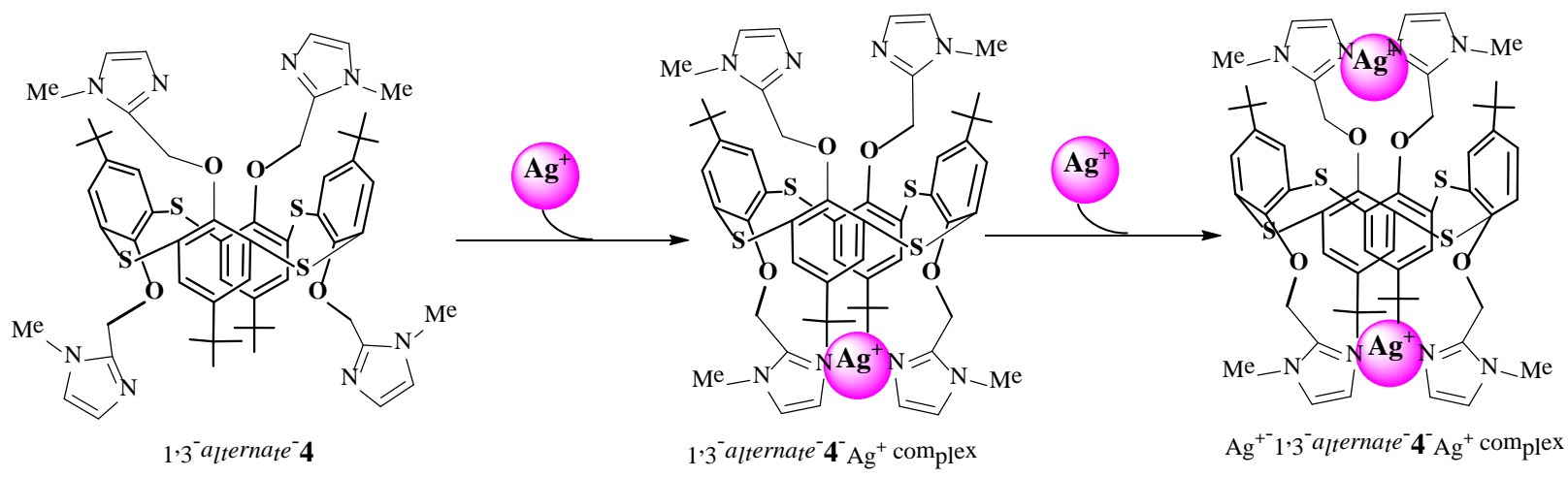

Fig. 7 Binding modes of 1,3-alternate-4 with $\mathrm{Ag}^{+}$. 


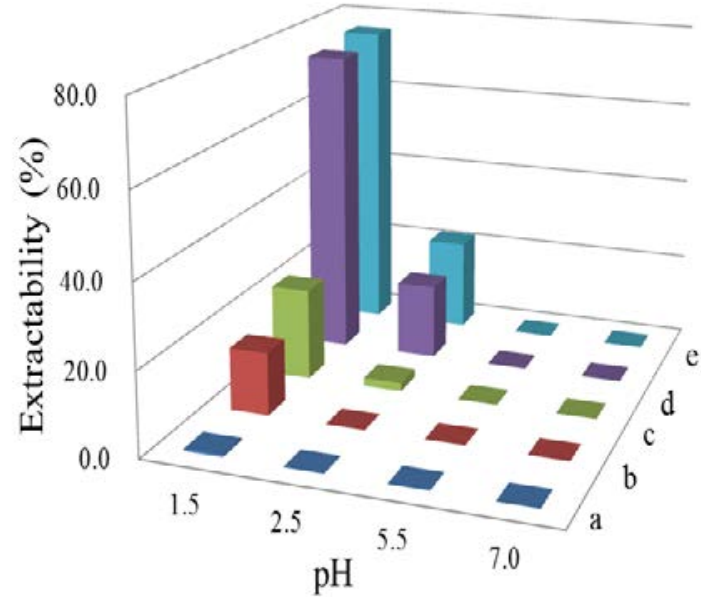

Fig. 8. Extraction percentages of dichromate anion with 1,3-alternate-4 and reference 6 at pH 1.5-7.0 $\left(\mathrm{H}_{2} \mathrm{O} / \mathrm{CH}_{2} \mathrm{Cl}_{2}: 10 / 10(\mathrm{v} / \mathrm{v}) ; \mathrm{K}_{2} \mathrm{Cr}_{2} \mathrm{O}_{7}=1 \times\right.$ $10^{-4} \mathrm{M}$; ligand: (a) reference 6, $4.0 \times 10^{-4} \mathrm{M}$; (b) 1,3-alternate-4, $0.5 \times$ $10^{-4} \mathrm{M}$; (c) 1,3-alternate-4, $1.0 \times 10^{-4} \mathrm{M}$; (d) 1,3-alternate-4, $2.0 \times 10^{-4}$ $\mathrm{M}$; (e) 1,3-alternate-4, $4.0 \times 10^{-4} \mathrm{M}, 1 \mathrm{~h}$ at $25^{\circ} \mathrm{C}$ ).

\section{Conclusion}

O-Alkylation of the flexible macrocycle thiacalix[4]arene 1 with 2chloromethyl-1-methyl- $1 \mathrm{H}$-imidazole 2 in the presence of $\mathrm{Na}_{2} \mathrm{CO}_{3}$ or $\mathrm{K}_{2} \mathrm{CO}_{3}$ afforded the mono-O-alkylation product 3 in $29-51 \%$ yield along with recovery of the starting compound. In contrast, the same reaction in the presence of $\mathrm{Cs}_{2} \mathrm{CO}_{3}$ gave only one pure stereoisomer 1,3-alternate-4, whilst the other possible isomers were not observed. Alkali metal cations can play an important role in the conformer distribution based on the template effect. Variation of the alkylation conditions and reagents can lead to the derivatives with different conformations, which can serve as interesting building blocks for larger potential host molecules. The present new imidazolesubstituted thiacalix[4]arene framework can effectively extract transition metal cations. The two-phase solvent extraction data indicated that the extraction of transition metals by tetrakis[2-(1-methyl$1 \mathrm{H}$-imidazolyl)methoxy]thiacalix[4]arene 1,3-alternate-4 was higher than the extraction of alkali metals. The results of the dichromate anion extraction for 1,3-alternate-4 showed that it can serve as a highly effective extractor for dichromate anions $\left(\mathrm{Cr}_{2} \mathrm{O}_{7}{ }^{2-} / \mathrm{HCr}_{2} \mathrm{O}_{7}{ }^{-}\right)$.

\section{Experimental Section}

\section{General}

All melting points were determined using a Yanagimoto MP-S1. ${ }^{1} \mathrm{H}$-NMR spectra were determined at $300 \mathrm{MHz}$ with a Nippon Denshi JEOL FT-300 NMR spectrometer with $\mathrm{SiMe}_{4}$ as an internal reference; $J$-values are given in $\mathrm{Hz}$. IR spectra were measured as $\mathrm{KBr}$ pellets or as liquid films on $\mathrm{NaCl}$ plates in a Nippon Denshi JIR-AQ2OM spectrophotometer. UV spectra were measured by a Shimadzu 240 spectrophotometer. Mass spectra were obtained on a Nippon Denshi JMS-01SG-2 mass spectrometer at an ionization energy of $70 \mathrm{eV}$ using a direct inlet system through GLC. Elemental analyses were performed by a Yanaco MT-5. G.L.C. analyses were performed with a Shimadzu gas chromatograph.

\section{Materials}

5,11,17,23-Tetra-tert-butyl-2,8,14,20-tetrathiacalix[4]arcne25,26,27,28-tetraol $\mathbf{I}$ was prepared from p-tert-butylphenol according to the reported procedure. ${ }^{16}$

\section{$\mathrm{O}$-Alkylation of 1 with 2-chloromethyl-1-methyl-1H-imidazole 2 in the presence of $\mathrm{Na}_{2} \mathrm{CO}_{3}$.}

A mixture of 1 (300 mg, $0.417 \mathrm{mmol}$ ) and $\mathrm{Na}_{2} \mathrm{CO}_{3}$ (885 mg, 8.34 $\mathrm{mmol})$ in dry acetone or acetonitrile $(50 \mathrm{~mL})$ was heated at reflux for $1 \mathrm{~h}$. Then 2-chloromethyl-1-methyl-1H-imidazole hydrochloride (2) (835 mg, $5.0 \mathrm{mmol}$ ) was added and the mixture heated at reflux for $24 \mathrm{~h}$ under argon. After cooling the reaction mixture to room temperature, it was filtered. The filtrate was concentrated and the residue was acidified with a $10 \% \mathrm{HCl}$ solution and extracted with $\mathrm{CH}_{2} \mathrm{Cl}_{2}$ (30 $\mathrm{mL} \times 3$ ), and the organic phase was washed with water $(40 \mathrm{~mL} \times 2)$ and then brine $(40 \mathrm{~mL})$. The organic phase was dried over $\mathrm{MgSO}_{4}$. The filtrate was evaporated to give a yellow oil, which was then washed with $\mathrm{MeOH}$ and hexane to give compound 3 (in acetone, $116 \mathrm{mg}, 30 \%$ ) and (in acetonitrile, $112 \mathrm{mg}, 29 \%$ ) as a white solid. Recrystallized from $\mathrm{CHCl}_{3}: \mathrm{MeOH}$ (3:1) afforded monosubstituted-3 as colourless prisms. M.p. 212-214 ${ }^{\circ} \mathrm{C}$. IR $v_{\max }$ $(\mathrm{KBr}) / \mathrm{cm}^{-1}$ 3374, 2961, 2867, 1635, 1586, 1557, 1536 and 1361; ${ }^{1} \mathrm{H}$ NMR (300 MHz, $\mathrm{CDCl}_{3}$ ): $\delta=0.34$ (s, 9H, tBu), 1.18 (s, 9H, $\left.t \mathrm{Bu}\right)$, 1.34 (s, $18 \mathrm{H}, t \mathrm{Bu}), 3.78$ (s, 3H, $\mathrm{NCH}_{3}$ ), 4.33 (s, 3H, $\mathrm{NCH}_{3}$ ), 6.05 (s, $2 \mathrm{H}, \mathrm{ArO}-\mathrm{CH}_{2}$-Imme), 6.41 (s, $2 \mathrm{H}$, Imme- $\mathrm{CH}_{2}-\mathrm{Imme}$ ), 6.87 (s, $1 \mathrm{H}$, Imme-H), 6.92 (s, 2H, Imme-H), 6.99 (s, $1 \mathrm{H}$, Imme-H), 7.38 (s, $1 \mathrm{H}$, $\mathrm{Ar}-H$ ), 7.47 (s, 2H, Ar-H), 7.60 (s, 2H, Ar-H), 7.65 (s, 3H, Ar-H) and 7.67 (s, $1 \mathrm{H}, \mathrm{OH}$ ) ppm. ${ }^{13} \mathrm{C}$ NMR $\left(\mathrm{CDCl}_{3}\right) \delta=29.9,31.6,33.4$, 33.5, 33.6, 34.0, 36.8, 44.7, 56.8, 121.7, 122.5, 123.1, 123.3, 123.9, 124.5, 127.8, 128.3, 131.9, 133.8, 134.3, 136.3, 136.8, 139.8, 140.7, 143.6, 148.4, 152.5, 157.9 and 166.1 ppm. FABMS: $\mathrm{m} / \mathrm{z} 909.42$ $\left(\mathrm{M}^{+}\right)$. Anal. Calcd. for $\mathrm{C}_{51} \mathrm{H}_{68} \mathrm{~N}_{4} \mathrm{O}_{7} \mathrm{~S}_{4}$ (977.33): $\mathrm{C}$ 62.68, $\mathrm{H}$ 7.01, N 5.73. found: C 62.68, H 6.83, N 5.80.

\section{O-Alkylation of 1 with 2-chloromethyl-1-methyl-1H-imidazole 2 in the presence of $\mathrm{K}_{2} \mathrm{CO}_{3}$.}

A mixture of 1 (300 mg, $0.417 \mathrm{mmol}$ ) and $\mathrm{K}_{2} \mathrm{CO}_{3}$ (1.15 g, 8.34 $\mathrm{mmol})$ in dry acetone $(50 \mathrm{~mL})$ was heated at reflux for $1 \mathrm{~h}$. Then 2chloromethyl-1-methyl- $1 H$-imidazole hydrochloride (2) (835 mg, $5.0 \mathrm{mmol}$ ) was added and the mixture heated at reflux for $24 \mathrm{~h}$ under argon. After cooling the reaction mixture to room temperature, it was filtered. The filtrate was concentrated and the residue was acidified with a $10 \% \mathrm{HCl}$ solution and extracted with $\mathrm{CH}_{2} \mathrm{Cl}_{2}(30 \mathrm{~mL} \times 3)$, and the organic phase was washed with water $(40 \mathrm{~mL} \times 2)$ and then brine $(40 \mathrm{~mL})$. The organic phase was dried over $\mathrm{MgSO}_{4}$. The filtrate was evaporated to give a yellow oil, which was then washed 
with $\mathrm{MeOH}$ and hexane to give compound 3 (193 mg, $51 \%$ ) as a white solid. Recrystallized from $\mathrm{CHCl}_{3}$ : $\mathrm{MeOH}$ (3:1) afforded mono-substituted-3 as colourless prisms.

\section{O-Alkylation of 1 with 2-chloromethyl-1-methyl-1H-imidazole 2 in the presence of $\mathrm{Cs}_{2} \mathrm{CO}_{3}$.}

A mixture of 1 (300 mg, $0.417 \mathrm{mmol}$ ) and $\mathrm{Cs}_{2} \mathrm{CO}_{3}$ (2.72 g, 8.34 $\mathrm{mmol})$ in dry acetone $(50 \mathrm{~mL})$ was heated at reflux for $1 \mathrm{~h}$. Then 2chloromethyl-1-methyl-1H-imidazole hydrochloride (2) (835 mg, $5.0 \mathrm{mmol}$ ) was added and the mixture heated at reflux for $24 \mathrm{~h}$ under argon. After cooling the reaction mixture to room temperature, it was filtered. The filtrate was concentrated and the residue was acidified with a $10 \% \mathrm{HCl}$ solution and extracted with $\mathrm{CH}_{2} \mathrm{Cl}_{2}(30 \mathrm{~mL} \times 3)$, and the organic phase was washed with water $(40 \mathrm{~mL} \times 2)$ and then brine $(40 \mathrm{~mL})$. The organic phase was dried over $\mathrm{MgSO}_{4}$. The filtrate was evaporated to give a yellow oil, which was then washed with $\mathrm{MeOH}$ and hexane to give 1,3-alternate-4 (300 mg, $66 \%$ ) as a white solid. Recrystallization from $\mathrm{CH}_{2} \mathrm{Cl}_{2}-\mathrm{MeCN}$ (3:1) afforded 1,3-alternate-4 as colourless prisms. M.p. 259-261 ${ }^{\circ} \mathrm{C}$; IR: $v_{\max }$ $(\mathrm{KBr}) / \mathrm{cm}^{-1}$ : 3056, 2961, 2906, 2870, 1635, 1574 and 1529; ${ }^{1} \mathrm{H}$ NMR $\left(300 \mathrm{MHz}, \mathrm{CDCl}_{3}\right) \delta=1.41$ (s, 36H, $\left.t \mathrm{Bu}\right), 2.51\left(12 \mathrm{H}, \mathrm{s}, N_{3} H_{3}\right), 5.17$ (s, 8H, ArOCH $\mathrm{Imme}_{2}$ ), 6.69 (s, 4H, Imme-H), 6.99 (s, 4H, Imme$H)$ and $7.26(8 \mathrm{H}, \mathrm{s}, \mathrm{Ar}-H) \mathrm{ppm} .{ }^{13} \mathrm{C} \mathrm{NMR}\left(\mathrm{CDCl}_{3}\right) \delta=31.5,32.8$, 34.4, 64.5, 122.2, 127.3, 128.9, 129.7, 143.2, 147.9 and $156.2 \mathrm{ppm}$. FABMS: $m / z: 1097.46\left(\mathrm{M}^{+}\right)$. Anal. calcd for $\mathrm{C}_{60} \mathrm{H}_{72} \mathrm{~N}_{8} \mathrm{O}_{4} \mathrm{~S}_{4}$ (1096.46): C 65.66, H 6.61, N 10.21. found: C 65.68, H 6.73, N 10.18 .

\section{Stoichiometry of metal complexation}

The method of continuous variation was employed to determine the stoichiometry in the complexes involving the host 1,3alternate-4. Two-phase solvent extraction was carried out between aqueous picrates $\left(5 \mathrm{~mL}\right.$, [metal picrate] $\left.=2.5 \times 10^{-4} \mathrm{M}\right)$ and host $\left(5 \mathrm{~mL}\right.$, [host] $=2.5 \times 10^{-4} \mathrm{M}$ in $\left.\mathrm{CH}_{2} \mathrm{Cl}_{2}\right)$. The two phase mixture in a glass tube was immersed in a thermostated water bath at $25{ }^{\circ} \mathrm{C}$ which was shaken at 300 strokes per min for $1 \mathrm{~h}$ and then kept at the same temperature for $2 \mathrm{~h}$, allowing the complete separation of the two phases. This was repeated 3 times. The absorbance of each solution was determined by UV spectroscopy $(\lambda=290 \mathrm{~nm})$. The molar ratios of both the host and metal picrate were varied from 0 to 1 , while the total concentration was kept at several constant levels. Job plots were generated by plotting the extracted $\left[\mathrm{M}^{+}\right]$versus the mole fraction of metal. We confirmed that this period was sufficient to attain the distribution equilibrium. The extractability was determined spectrophoto-chemically from the decrease in the absorbance of the picrate ion in the aqueous phase, as described by Pedersen. ${ }^{17}$

\section{${ }^{1}$ H-NMR complexation experiments}

To a $\mathrm{CDCl}_{3} / \mathrm{CD}_{3} \mathrm{CN}\left(\mathrm{v} / \mathrm{v} 10: 1,8 \times 10^{-3} \mathrm{M}\right)$ solution of 1 ,3-alternate4 in an NMR tube was added a $\mathrm{CDCl}_{3} / \mathrm{CD}_{3} \mathrm{CN}\left(\mathrm{v} / \mathrm{v} 10: 1,4 \times 10^{-3} \mathrm{M}\right)$ solution of $\mathrm{AgClO}_{4}$. The spectra were recorded after the addition and the temperature of the NMR probe was kept constant at $27^{\circ} \mathrm{C}$.

\section{Crystallographic analyses of 3 and 1,3-alternate-4}

Diffraction data were collected on a Bruker APEX 2 CCD diffractometer equipped with graphite-monochromated Mo-Ka radiation at $150(2) \mathrm{K} .{ }^{18}$ Data were corrected for Lorentz and polarisation effects and for absorption. ${ }^{18}$ The structures were solved by direct methods and refined by full-matrix least-squares methods, on $F^{2} \cdot{ }^{19} \mathrm{H}$ atoms were refined using a riding model except for those on hetero atoms in $\mathbf{3}$ which were freely refined. In $\mathbf{3}$ the entrire $\mathrm{tBu}$ group at $\mathrm{C}(7)$ was refined as two-fold disordered with major componente occupancy of 59.2(7)\%, while tBu groups at $\mathrm{C}(27)$ and $\mathrm{C}(37)$ were modelled with the methyl groups two-fold disordered with major occupancies of 53.7(6) and 85.5(6)\% respectively.

Crystal data for 3: $\mathrm{C}_{51} \mathrm{H}_{68} \mathrm{~N}_{4} \mathrm{O}_{7} \mathrm{~S}_{4}, \mathrm{M}=977.33$. Orthorhombic, space group Pbca, $a=13.2947(5), b=21.6351(9), c=37.7271(15) \AA, V=$ $10851.5(7) \AA^{3} . Z=8, D c=1.196$ g.cm ${ }^{-3}, F(000)=4176, T=150(2)$ $\mathrm{K}, \mu(\mathrm{Mo}-\mathrm{K} \alpha)=0.226 \mathrm{~cm}^{-1}, \lambda(\mathrm{Mo}-\mathrm{K} \alpha)=0.71073 \AA$, colourless crystal of size $0.67 \times 0.25 \times 0.10 \mathrm{~mm}^{3}$. The total number of reflections measured, to $\theta_{\max }=27.20^{\circ}$, was 98199 of which 12054 were unique $\left(R_{\text {int }}=0.0537\right)$; 8953 were 'observed' with $I>2 \sigma(I)$. For the 'observed' data only, $R_{1}=0.0497 ; \mathrm{w} R_{2}=0.1426$ for all 12054 reflections and 715 parameters. Residual electron density within $+/-0.621 \mathrm{e}^{-3}$.

Crystal data for 1,3-alternate-4: Crystal data: $\mathrm{C}_{60} \mathrm{H}_{72} \mathrm{~N}_{8} \mathrm{O}_{4} \mathrm{~S}_{4}, \mathrm{M}=$ 1097.50. Tetragonal, space group, $I 4_{1} / a, a=19.530(2), c=$ 15.3376(16) $\AA, V=5849.8(10) \AA^{3} . Z=4, D c=1.246 \mathrm{~g} \cdot \mathrm{cm}^{-3}$, $F(000)=2336, T=150(2) \mathrm{K}, \mu(\mathrm{Mo}-\mathrm{K} \alpha)=0.215 \mathrm{~cm}^{-1}, \lambda(\mathrm{Mo}-\mathrm{K} \alpha)=$ $0.71073 \AA$. Colourless Crystal of size $0.24 \times 0.12 \times 0.10 \mathrm{~mm}^{3}$. The total number of reflections recorded, to $\theta_{\max }=27.20^{\circ}$, was 25807 of which 3254 were unique $\left(R_{\text {int }}=0.0776\right) ; 2220$ were 'observed' with $I>2 \sigma(I)$. For the 'observed' data only, $R_{1}=0.0401 ; \mathrm{w} R_{2}=0.0899$ for all 3254 reflections. Residual electron density within $+/-0.291$ $\mathrm{e} \AA^{-3}$.

Crystallographic data (excluding structure factors) for the structures in this paper have been deposited with the Cambridge Crystallographic Data Centre as supplementary publication numbers CCDC 997019 for 3 and 997001 for 1,3-alternate-4, respectively. Copies of the data can be obtained, free of charge, on application to CCDC, 12 Union Road, Cambridge CB2 1EZ, UK [fax: 144-1223336033 or e-mail: deposit@ccdc.cam.ac.uk].

Supporting information: ${ }^{1} \mathrm{H},{ }^{13} \mathrm{C}$ NMR \& IR spectra of compound $\mathbf{3}$ and 1,3-alternate-4.

\section{Acknowledgements}

This work was performed under the Cooperative Research Program of "Network Joint Research Center for Materials and Devices (Institute for Materials Chemistry and Engineering, Kyushu University)". We would like to thank the OTEC at Saga University and the International Cooperation Projects of Guizhou Province (No. 20137002), The Royal Society of Chemistry for financial support and the EPSRC for an overseas travel grant to C.R.

\section{Notes and references}


a Department of Applied Chemistry, Faculty of Science and Engineering, Saga University, Honjo-machi 1, Saga 840-8502 Japan, E-mail: yamatot@cc.saga-u.ac.jp.

${ }^{\mathrm{b}}$ Department Key Laboratory of Macrocyclic and Supramolecular Chemistry of Guizhou Province, Guizhou University, Guiyang, Guizhou, 550025, China. c Chemistry Department, Loughborough University, Loughborough, LE11 3TU, UK.

${ }^{d}$ Department of Chemistry, The University of Hull, Cottingham Road, Hull, Yorkshire, HU6 7RX, UK.

$\dagger$ Electronic Supplementary Information (ESI) available: Details of single-crystal X-ray crystallographic data. For ESI and crystallographic data in CIF see DOI: 10.1039/b000000x/

1 (a) F. Sansone, E. Chierici, A. Casnati and R. Ungaro, Org. Biomol. Chem., 2003, 1, 1802-1809; (b) Y. Israeli, G. A. Facey and C. Detellier, Magn. Reson. Chem. 2004, 42, 573-576; (c) G. Gattuso, R. Liantonio, P. Metrangolo, F. Meyer, A. Pappalardo, M. F. Parisi, T. Pilati, I. Pisagatti and G. Resnati, Supramol. Chem., 2006, 18, 235-243; (d) K. Salorinne and M. Nissinen, J. Incl. Phenom. Macrocyclic Chem., 2008, 61, 11-27; (e) A. R. Hajipour, S. Habibi and A. E. Ruoho, Polym. Adv. Technol., 2009, 20, 1050-1059; ( $f$ ) I. Qureshi, S. Memon and M. Yilmaz, J. Hazard. Materials, 2009, 164, 675-682; (j) S. Licen, V. Bagnacani, L. Baldini, A. Casnati, F. Sansone, M. Giannetto, P. Pengo and P. Tecilla, Supramol.Chem., 2013, 25, 631-640.

2 (a) R. E. Brewster, K. L. Caran, J. S. Sasine and S. B. Shuker, Curr. Org. Chem., 2004, 8, 867-881; (b) R. Ludwig, Microchim. Acta, 2005, 152, 1-19; (c) R. V. Rodik, V. I. Boyko and V. I. Kalchenko, Curr. Med. Chem., 2009, 16, 1630-1655; (d) N. de Silva, J.-M. Ha, A. Solovyov, M. M. Nigra, I. Ogino, S. W. Yeh, K. A. Durkin and A. Katz, Nat. Chem., 2010, 2, 1062-1068; (e) D. T. Schuehle, J. A. Peters and J. Schatz, Coord. Chem. Rev., 2011, 255, 2727-2745; $(f)$ B. Tabakci, M. Yilmaz and A. D. Beduk, J. Appl. Polym. Sci., 2012, 125, 1012-1019.

3 (a) S. W. Oh, J. D. Moon, H. J. Lim, S. Y. Park, T. Kim, J. Park, M. H. Han, M. Snyder and E. Y. Choi, Faseb J., 2005, 19, 1335-1337; (b) C. G. Oliveri, N. C. Gianneschi, S. T. Nguyen, C. A. Mirkin, C. L. Stern, Z. Wawrzak and M. Pink, J. Am. Chem. Soc., 2006, 128, 16286-16296; (c) R. Zadmard and T. Schrader, Angew. Chem. Int. Edit., 2006, 45, 2703-2706; (d) L. Baldini, A. Casnati, F. Sansone and R. Ungaro, Chem. Soc. Rev., 2007, 36, 254-266; (e) N. de Silva, J.-M. Ha, A. Solovyov, M. M. Nigra, I. Ogino, S. W. Yeh, K. A. Durkin and A. Katz, Nat. Chem., 2010, 2, 1062-1068; (f) H. N. Kim, W. X. Ren, J. S. Kim and J. Yoon, Chem. Soc. Rev., 2012, 41, 32103244.

4 (a) Y. Rondelez, M. N. Rager, A. Duprat and O. Reinaud, J. Am. Chem. Soc., 2002, 124, 1334-1340; (b) U. Darbost, O. Sénèque, Y. Li, G. Bertho, J. Marrot, M. N. Rager, O. Reinaud and I. Jabin, Chem. Eur. J. 2007, 13, 2078-2088; (c) U. Darbost, X. Zeng, M. N. Rager, M. Giorgi, I. Jabin and O. Reinaud, Eur. J. Inorg. Chem., 2004, 22, 4371-4374; (d) O. Sénèque, M. N. Rager, M. Giorgi and O. Reinaud, J. Am. Chem. Soc., 2000, 122(26), 6183-6189; (e) Y. Rondelez, O. Sénèque, M. N. Rager, A. Duprat and O. Reinaud, Chem. Eur.
J., 2000, 6, 4218-4226; ( $f$ ) O. Sénèque, M. N. Rager, M. Giorgi and O. Reinaud, J. Am. Chem. Soc., 2000, 122, 61836189.

5 (a) O. Seneque, M. N. Rager, M. Giorgi, T. Prange, A. Tomas and O. Reinaud, J. Am. Chem. Soc., 2005, 127, 14833-14840; (b) J. J. R. Frausto da Silva and R. J. P. Williams, The Biological Chemistry of the Elements: The Inorganic Chemistry of the life, Oxford University Press, Oxford, 2001; (c) E. I. Solomon, M. J. Badwin and M. D. Lowery, Chem. Rev. 1992, 92, 521-542.

6 (a) I. Törö, P. Surdy, A. Rockenbauer, L. K. Jr, G. J. A. A. Koolhaas and T. Gajda, J. Inorg. Biochem., 1998, 71, 7-14; (b) K. ösz, K. Várnagy, H. Vargha, D. Sanna, G. Micera and I. Sóvágó, Inorg. Chim. Acta, 2002, 339, 373-382; (c) M. A. Neelakantan and M. N. Sivasankaran, Iran. J. Chem. \& Chem. Eng., 2004, 23, 97-102.

7 (a) L. L. Clainche, M. Giorgi and O. Reinaud, Inorg. Chem., 2000, 39, 3436-3437; (b) O. Seneque, M. N. Rager, M. Giorgi, T. Prange, A. Tomas and O. Reinaud, J. Am. Chem. Soc., 2005, 127, 14833-14840.

8 (a) Y. D. Cao, Q. Y. Zheng, C. F. Chen and Z. T. Huang, Tetrahedron Lett., 2003, 44, 4751-4755; (b) Y. D. Cao, Q. Y. Zheng, C. F. Chen and Z. T. Huang, J. Chem. Res.-S, 2003, 489-490; (c) Y. D. Cao, Q. Y. Zheng, C. F. Chen, H. M. Hu and Z. T. Huang, Inorg. Chim. Acta, 2004, 357, 316-320.

9 (a) Y. Liu, Z. Li, H.-Y. Zhang, H. Wang and C.-J. Li, Supramol. Chem., 2008, 20, 419-426; (b) C. E. Willans, K. M. Anderson, L. C. Potts and J. W. Steed, Org. Biomol. Chem., 2009, 7, 2756-2760.

10 (a) C. Raji and T. S. Anirudhan, Water Res., 1998, 32, 37723780; (b) N. Goyal, S. C. Jain and U. C. Banerjee, Adv. Environ. Res., 2003, 7, 311-319.

11 I. B. Solangi, F. Özcan, G. Arslan and M. Ersöz, Separation and Purification Technology, 2013, 118, 470-478.

12 (a) J. M. Harrowfield, M. I. Ogden, W. R. Richmond and A. H. White, J. Chem. Soc., Chem. Commun., 1991, 1159-1160; (b) Calixarenes 50th Anniversary: Commemorative Volume, ed. J. Vicens, Z. Asfari and J. M. Harrowfield, Kluwer Academic, Dordrecht, 1995.

13 T. Yamato, M. Haraguchi, J.-I. Nishikawa, S. Ide and H. Tsuzuki, Can. J. Chem., 1998, 76, 989-996.

14 X. L. Ni, C. C. Jin, X. K. Jiang, M. Takimoto, S. Rahman, X. Zeng, D. L. Hughes, C. Redshaw and T. Yamato, Org Biomol Chem, 2013, 11, 5435-5442.

15 (a) S. Sayin, F. Ozcan and M. Yilmaz, Mat. Sci. Eng. C-Mater, 2013, 33, 2433-2439; (b) S. Sayin, M. Yilmaz and M. Tavasli, Tetrahedron, 2011, 67, 3743-3753; (c) S. Bozkurt, E. Kocabas, M. Durmaz, M. Yilmaz and A. Sirit, J. Hazard. Mater., 2009, 165, 974-979; (d) M. Bayrakc1, Ş. Ertul and M. Yilmaz, Tetrahedron, 2009, 65, 7963-7968; (e M. Tabakci, S. Memon and M. Yilmaz, Tetrahedron, 2007, 63, 6861-6865; $(f)$ A. Yilmaz, S. Memon and M. Yilmaz, Tetrahedron, 2002, 58, 7735-7740.

16 H. Kumagai, M. Hasegawa, S. Miyanari, Y. Sugawa, Y. Sato, T. Hori, S. Ueda, H. Kamiyama and S. Miyano, Tetrahedron Lett., 1997, 38, 3971-3972. 
17 (a) C. J. Pedersen, J. Am. Chem. Soc., 1967, 89, 7017-7036;

(b) C. J. Pedersen, J. Am. Chem. Soc., 1967,89, 2495-2496; (c) C. J. Pedersen, J. Am. Chem. Soc., 1970, 92, 391-394..

18 SAINT and APEX 2 (2008) software for CCD diffractometers. Bruker AXS Inc., Madison, USA

19 G. M. Sheldrick, Acta Crystallogr., 2008, A64, 112-122. 